\title{
Copper Based Bulk Metallic Glasses for Medical Devices
}

CARMEN OPRIȘ*, COSMIN CODREAN, DRAGOS BUZDUGAN, PETRU HIDIDIȘ

Politehnica University Timișoara, Materials and Manufacturing Engineering Department, Romania, 1 Mihai Viteazul Blvd., 300222, Timișoara, Romania

Bulk metallic glasses (BMGs) represent a viable alternative for replacing classic materials used in medical devices. This paper presents the research conducted in order to obtain copper based BMGs using two different chemical compositions: $\mathrm{Cu}_{48} \mathrm{Zr}_{47} \mathrm{Al} \mathrm{l}_{5}$ and $\mathrm{Cu}_{45} \mathrm{Zr}_{45} \mathrm{Al}_{5} \mathrm{Ag} \mathrm{g}_{5}$. The samples were obtained by copper mold casting and their structure and properties were investigated using X-Ray diffraction (XRD), differential scanning calorimetry (DSC) and optical microscopy.

Keywords: Bulk metallic glasses, GFA, copper, medical devices

Biocompatible materials play a key role in the construction of medical devices currently used on a large scale [1-4]. Recent researches were focused on developing new materials that would not inherit the disadvantages of the classic materials (poor corrosion resistance, low deformability etc) [5-19]. Bulk metallic glasses (BMG) can be a viable alternative for replacing classic biocompatible materials $[18,19]$, due to their specific properties such as: good corrosion resistance in the absence of intercrystalline corrosion, excellent plastic deformability and good castability (absence of casting defects and voids that form when casting crystalline structure materials) even with complex geometries. This sum of properties makes the BMGs very appealing for medical devices.

After the first metallic glass of $\mathrm{Au}_{75} \mathrm{Si}_{25}$ was developed in the 1960's [11], intensive research were conducted in order to obtain BMGs using different elements including $\mathrm{Zr}, \mathrm{Ni}, \mathrm{Ti}, \mathrm{Fe}, \mathrm{Au}, \mathrm{Pt}, \mathrm{Cu}$ as a base for these outstanding materials. Various methods of obtaining BMGs were developed, dealing with problems related to raw materials (their purity), complicated equipment and process, mechanical properties of the products (generally the BMGs are brittle) [5-19]. Recent studies are focused on discovering new alloying strategies including new materials combinations, processing methods, new structures (nanocrystalline or nanoquasicrystalline particles) as well as exploring new properties (such as magnetic, chemical or physical).

This study was aimed to assess the influence of silver on the structure and properties of bulk metallic glasses with biocompatible properties from the $\mathrm{Cu}-\mathrm{Zr}-\mathrm{Al}$ respectively $\mathrm{Cu}-\mathrm{Zr}-\mathrm{Al}-\mathrm{Ag}$ system. Also, since obtaining BMGs usually require special preparation conditions such as vacuum or controlled atmosphere, this study aims to develop a method to obtain them by air casting method, in the form of $3 \mathrm{~mm}$ rods, with no special conditions.

\section{Experimental part}

Pure elements $\mathrm{Cu}, \mathrm{Zr}, \mathrm{Al}$ and $\mathrm{Ag}$ were mixed together, than the mixture was melted using an Arc Melter AM 200 furnace, obtaining thus 10 grams batches of $\mathrm{Cu}_{48} \mathrm{Zr}_{47} \mathrm{Al}_{5}$ and $\mathrm{Cu}_{45} \mathrm{Zr}_{45} \mathrm{Al}_{5} \mathrm{Ag}_{5}$ master alloys. Afterwards, the master alloys were re-melted and casted using a copper mold, obtaining rods with $3 \mathrm{~mm}$ diameter and $100 \mathrm{~mm}$ length. No special conditions were required during casting, as the process was conducted at room atmosphere.

The structure of the samples was investigated using SEM/EDAX and X-ray diffraction XRD. X-ray diffraction was conducted using an $\mathrm{X}^{\prime}$ Pert ${ }^{3}$ Powder diffraction system, with the radiation of a $\mathrm{Cu}$ anode with a wavelength $\lambda=1.54 \AA$. Differential scanning calorimetry (DSC) was used to investigate the thermal stability, on a Netzsch STA 441 Jupiter apparatus under a flow of purified nitrogen. The glass transition temperature $T_{g}$, the crystallization temperature $T_{x}$ and the melting temperature $\mathrm{T}_{\mathrm{m}}$ were determined as the onset temperatures of the glass transition the crystallization and melting peak, respectively, and the liquidus temperature $T_{1}$ as the offset of the melting peak during heating with a constant rate of $0.33 \mathrm{~K} / \mathrm{s}$.

Vickers hardness HV was measured using a Wolpert Micro-Vickers Hardness Tester machine at room temperature using a 100 grams load. At least 10 measurements were conducted, in order to ensure the accuracy of the results. Olympus BX51M microscope with Analysis 5.0 software was used to microscopically analyze the alloys microstructure.

\section{Results and discussions}

In order to confirm the structural homogeneity of the master alloys, SEM analysis was conducted on both batches. The images are presented in figure 1.

\footnotetext{
*email: carmen.opris@upt.ro
} 

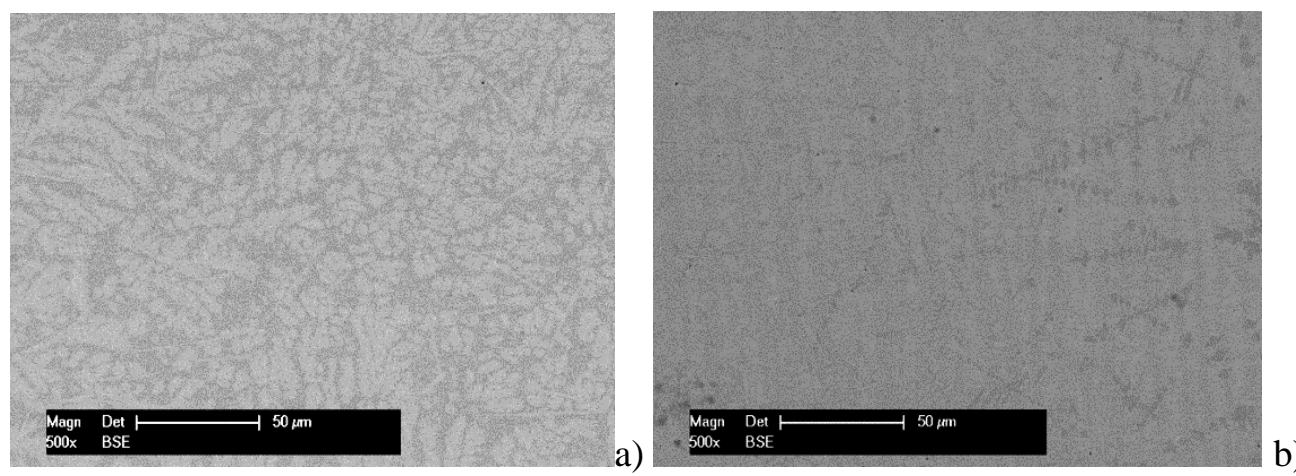

Fig. 1 SEM image of the master alloys: a) $\mathrm{Cu}_{48} \mathrm{Zr}_{47} \mathrm{Al}_{5}$, b) $\mathrm{Cu}_{45} \mathrm{Zr}_{45} \mathrm{Al}_{5} \mathrm{Ag}_{5}$

The $\mathrm{Cu}_{48} \mathrm{Zr}_{47} \mathrm{Al}_{5}$ alloy shows a casting structure with dendrites, specific to crystalline materials, while the $\mathrm{Cu}_{45} \mathrm{Zr}_{45} \mathrm{Al}_{5} \mathrm{Ag}_{5}$ alloy exhibits only slight traces of dendrites embedded in an eutectic structure, indicating thus a higher amorphization susceptibility. X-ray diffraction shows the presence of high peaks for the $\mathrm{Cu}_{48} \mathrm{Zr}_{47} \mathrm{Al}_{5}$ master alloy (figure 2a), characteristic to crystalline materials, which together with the low eutectic quantity indicate a lower glass forming ability (GFA). The second X-ray diffraction (figure $2 \mathrm{~b}$ ) confirms the results given by the SEM image, that the alloy $\mathrm{Cu}_{45} \mathrm{Zr}_{45} \mathrm{Al}_{5} \mathrm{Ag}_{5}$ is suitable for amorphization.
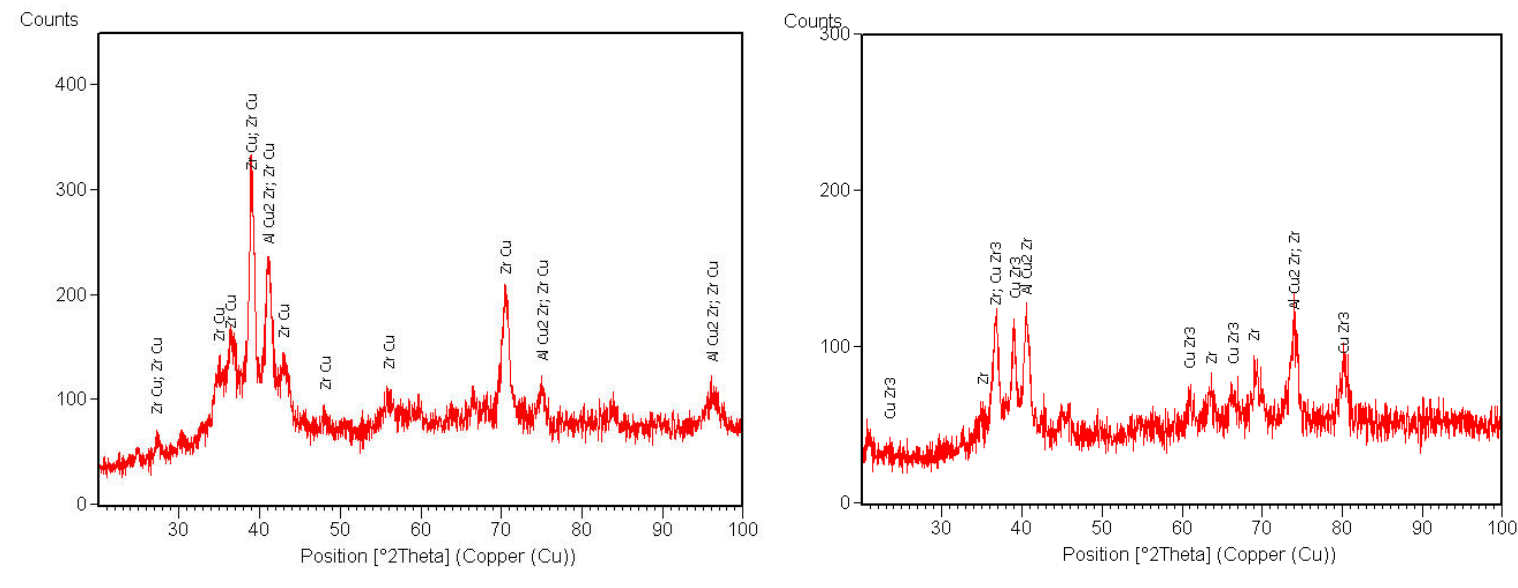

a. $\mathrm{Cu}_{48} \mathrm{Zr}_{47} \mathrm{Al}_{5}$

b. $\mathrm{Cu}_{45} \mathrm{Zr}_{45} \mathrm{Al}_{5} \mathrm{Ag}_{5}$

Fig. 2 X-Ray diffraction of the master alloys: a) $\mathrm{Cu}_{48} \mathrm{Zr}_{47} \mathrm{Al}_{5}$, b) $\mathrm{Cu}_{45} \mathrm{Zr}_{45} \mathrm{Al}_{5} \mathrm{Ag}_{5}$

The rods casted in a copper mold (figure 3) were macroscopically analyzed. The examination emphasized the metallic luster and the absence of defects such as pores or cracks.

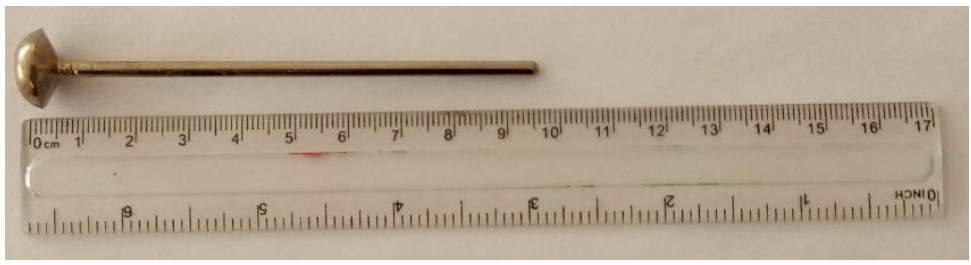

Fig. 3 Macroscopic aspect of the casted sample

The presence of broad peaks in diffraction image (figure 4) confirms that the structure is amorphous only for the $\mathrm{Cu}_{45} \mathrm{Zr}_{45} \mathrm{Al}_{5} \mathrm{Ag}_{5}$ alloy. The structure of the $\mathrm{Cu}_{48} \mathrm{Zr}_{47} \mathrm{Al}_{5}$ alloy is microcrystalline, with peaks corresponding to compounds such as $\mathrm{CuZr}_{3}, \mathrm{ZrCu}, \mathrm{Zr}_{2} \mathrm{Cu}, \mathrm{Zr}_{2} \mathrm{Al}$ and $\mathrm{Zr}$. 


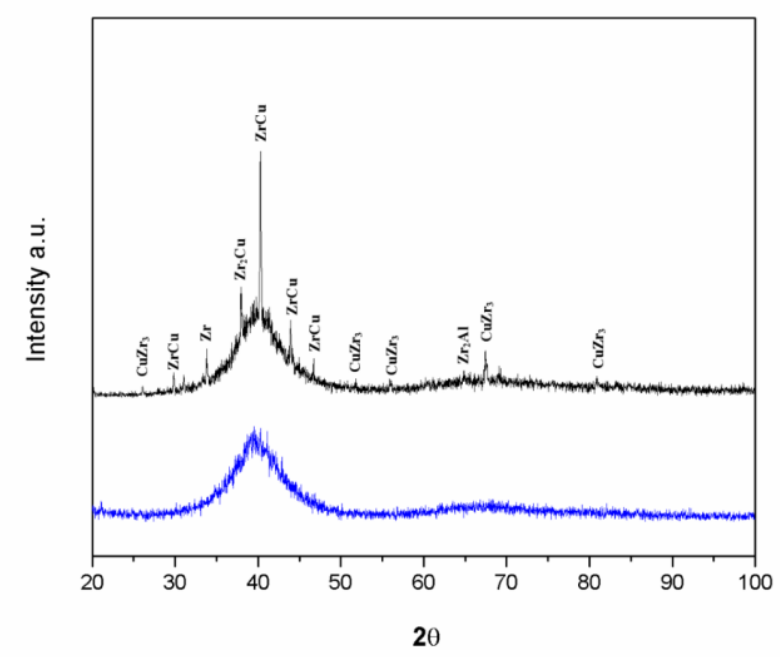

Fig. 4 XRD image of the casted samples

The DSC curves of the samples are showed in Figure 5.

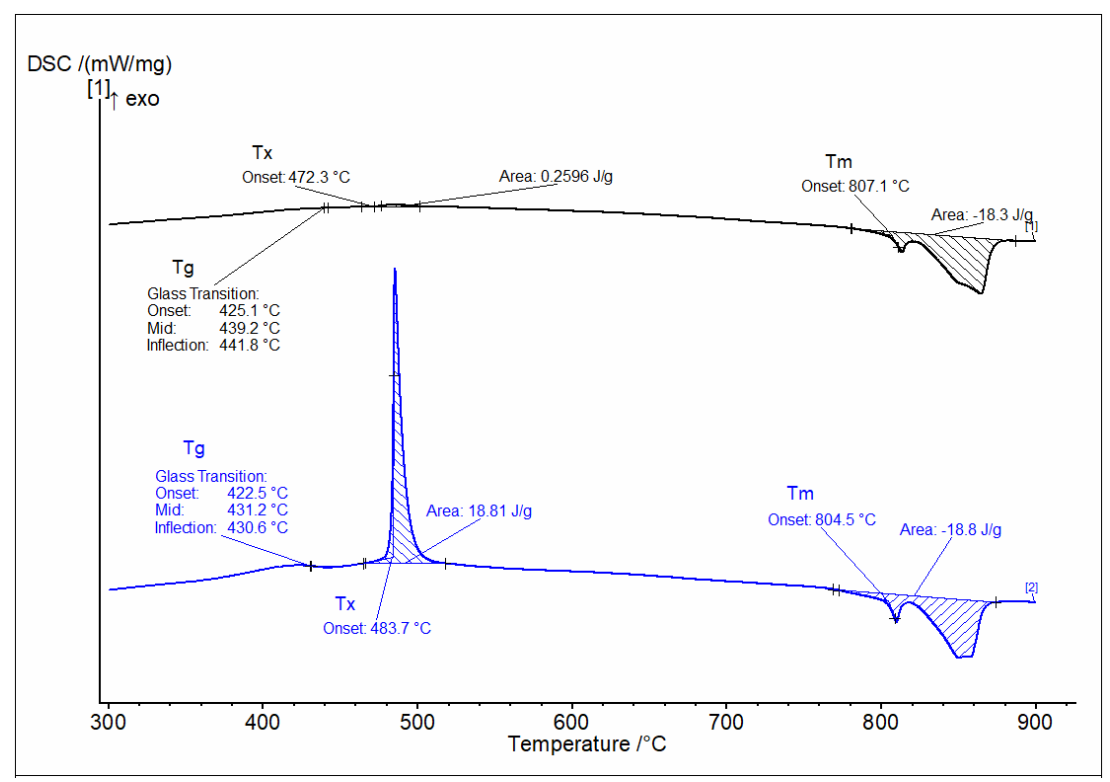

Fig. 5 DSC curves of the casted samples

In case of the $\mathrm{Cu}_{48} \mathrm{Zr}_{47} \mathrm{Al}_{5}$ alloy, the DSC curve shows an exothermic inflexion which marks the recrystallization of the microcrystalline metastable phase, obtaining as a result of the rapid cooling. Heating over $\mathrm{T}_{\mathrm{x}}=472^{\circ} \mathrm{C}$ leads to obtaining a crystalline structure, similar to the master alloy.

In case of the $\mathrm{Cu}_{45} \mathrm{Zr}_{45} \mathrm{Al}_{5} \mathrm{Ag}_{5}$ alloy the DSC curve exhibits an exothermic peak which marks the crystallization event and an endothermic peak for the melting. The glass transition temperatures $T_{g}$, the crystallization temperatures $T_{x}$ and the $\Delta \mathrm{T}_{\mathrm{x}}=\mathrm{T}_{\mathrm{x}}-\mathrm{T}_{\mathrm{g}}$ parameter which estimates the glass forming ability was calculated for this alloy. The values are listed in table 1. For a good GFA the supercooled liquid region $\Delta \mathrm{T}_{\mathrm{x}}$, should be as large as possible [19], while a high $\mathrm{T}_{\mathrm{x}}$ means a higher stability of the glass.

Table 1

THERMAL AND MECHANICAL PROPERTIES OF THE SAMPLES

\begin{tabular}{|l|l|l|l|l|l|}
\hline Sample & $\mathrm{T}_{\mathrm{g}}\left({ }^{\circ} \mathrm{C}\right)$ & $\mathrm{T}_{\mathrm{x}}\left[{ }^{\circ} \mathrm{C}\right]$ & $\Delta \mathrm{T}_{\mathrm{x}}$ & $\mathrm{T}_{\mathrm{m}}\left[{ }^{\circ} \mathrm{C}\right]$ & $\mathrm{HV} 0.1$ \\
\hline $\mathrm{Cu}_{48} \mathrm{Zr}_{4} 7 \mathrm{Al}_{5}$ & - & 472 & - & 807 & $423 \pm 5$ \\
\hline $\mathrm{Cu}_{45} \mathrm{Zr}_{45} \mathrm{Al}_{5} \mathrm{Ag}_{5}$ & 430 & 487 & 57 & 804 & $396 \pm 6$ \\
\hline
\end{tabular}

It can be seen from table 1 that the addition of silver ensures the glass transition temperature $\mathrm{T}_{\mathrm{g}}$ of $430^{\circ} \mathrm{C}$ and a good the thermal stability, with crystallization temperature $T_{x}$ of $487^{\circ} \mathrm{C}$. Meanwhile, the melting temperature slightly moves 
to lower values. $\Delta \mathrm{T}_{\mathrm{x}}$, the most common parameter used to determine the GFA, is $57^{\circ} \mathrm{C}$ for the alloy that contains the $\mathrm{Ag}$ addition and it is well known that a high value for $\Delta \mathrm{T}_{\mathrm{x}}$ ensures a good GFA.

Regarding the mechanical properties, it was found that the alloys containing silver have a slightly lower microhardness than the $\mathrm{Cu}_{48} \mathrm{Zr}_{47} \mathrm{Al}_{5}$ alloy.

Since silver tends to form eutectics with $\mathrm{Cu}, \mathrm{Zr}, \mathrm{Al}$, according to the confusion principle, addition of silver to the chemical composition leads to the formation of a quaternary eutectic. As a result, the melting temperature decreases and it favors the transformation of the liquid into an amorphous solid. Meanwhile, it is well known that silver has low hardness and its tendency of forming solid solutions with $\mathrm{Cu}, \mathrm{Al}, \mathrm{Zr}$ can explain the decrease of hardness exhibit by the $\mathrm{Cu}_{45} \mathrm{Zr}_{45} \mathrm{Al}_{5} \mathrm{Ag}_{5}$ alloy [20].

The microscopic image of the arc melted $\mathrm{Cu}_{45} \mathrm{Zr}_{45} \mathrm{Al}_{5} \mathrm{Ag}_{5}$ alloy (Figure 6) presents two compounds with distinct shapes precipitated in the matrix. Different studies $[5,16]$ reported the presence of structures similar to those presented in this research. After casting, the structure is refining, but does not substantially change (Figure 7).

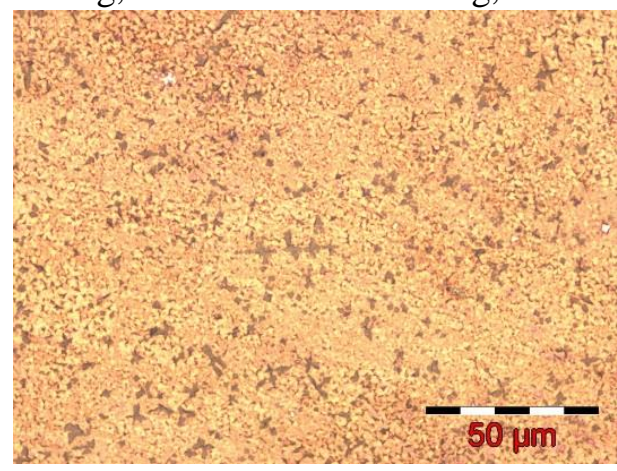

Fig. 6 Microscopic image of the arc melted $\mathrm{Cu}_{45} \mathrm{Zr}_{45} \mathrm{Al}_{5} \mathrm{Ag}_{5}$ alloy

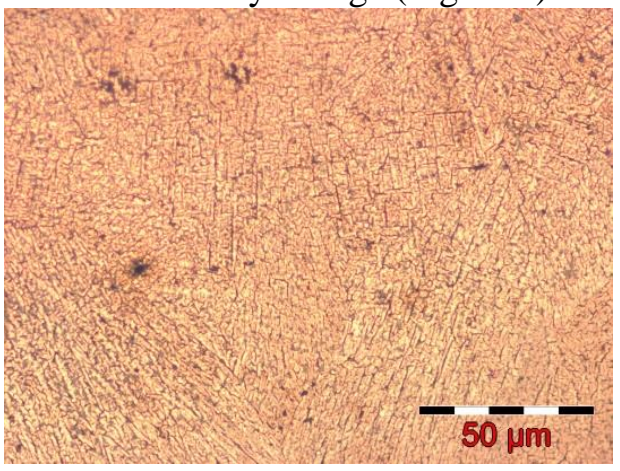

Fig. 7 Microscopic image of casted $\mathrm{Cu}_{45} \mathrm{Zr}_{45} \mathrm{Al}_{5} \mathrm{Ag}_{5}$ alloy

\section{Conclusions}

$\mathrm{Cu}_{48} \mathrm{Zr}_{47} \mathrm{Al}_{5}$ and $\mathrm{Cu}_{45} \mathrm{Zr}_{45} \mathrm{Al}_{5} \mathrm{Ag}_{5}$ bulk metallic glasses were obtained in the shape of $3 \mathrm{~mm}$ diameter and $100 \mathrm{~mm}$ length rods using the copper mod casting method. The novelty consists of the fact that no special conditions were required during casting, as the process was conducted at room atmosphere.

It was found that the addition of silver in the chemical composition leads to a value for $\Delta \mathrm{T}_{\mathrm{x}}$ (the most common parameter used to determine the GFA) of $57^{\circ} \mathrm{C}$. However, the hardness decreases slightly when adding silver in the chemical composition of the alloy. Considering the results, further investigations are required for these alloy class and future tests will include compression and corrosion tests.

Acknowledgments: This work was supported by research grant GNaC2018 - ARUT, no. 1358/01.02.2019, financed by Politehnica University of Timisoara.

\section{References}

1.TATU, ROMULUS F., IVASCHESCU, V., BOJIN, F., HURMUZ, M., TATU, C.., A Mechanical Vibration Method Used to Investigate the Evolution of Fractures Fixed with Biocompatible Materials, Mat. Plast., 51 , no. 1, 2014, p. 28-31

2.SZABO, A., BORDEASU, I., UTU, I. D., MITELEA, I., In vitro Behaviour of Alumina-Hydroxiapatite Composites Coatings, Rev. Chim (Bucharest), 69, no.6, 2018, p. 1416-1418

3.FEIER, A. M., MANU, D.R., STRNAD, G., DOBREANU, M., RUSSU, O.M., PORTAN, D., BATAGA ,T., A Step Forward

Standardization of Biocompatibility Testingon Tissue Culture Polystyrene, Mat. Plast., 55, no. 3, 2018, p. 303 -307

4.TUDORAN, M., TUDORAN, C., CIOCARLIE, T., POP, G. N., BERCEANU-VADUVA, M. M., VELIMIROVICI, D.E., AHMED, A.

A., BERCEANU-VADUVA, D. M., Aspects of Heart Failure in Patients with Ischemic Heart Disease after Percutaneous Coronary

Revascularization with Polymer-coated Drug-Eluting Stents versus Bare-Metal Stents, Mat. Plast., 56, no. 1, 2019, p. 37-40

5.LIU, Y., BLANDIN, J.J,, SUERY, M., KAPELSKI, G., Effect of cooling rate on the microstructure and microhardness of the CuZrAgAl alloy. Materials Characterization. 70, 2012, p.8-13.

6.SURYANARAYANA, C., INOUE, A., Bulk metallic glasses, CRC Press, Boca Raton, FL, 2011.

7.STOICA, M., Fe-based bulk metallic glasses: understanding the influence of impurities on glass formation, Springer, Wiesbaden, 2017.

8.FAN, C., TAKEUCHI, A., INOUE, A., Preparation and Mechanical Properties of Zr-based Bulk Nanocrystalline Alloys Containing Compound and Amorphous Phases. Materials Transactions, JIM. 40(1), 1999, p.42-51.

9.WANG, W.H., DONG, C., SHEK, C.H., Bulk metallic glasses, Materials Science and Engineering: R: Reports. 44, 2004, p.45-89.

10.LU, Z.P., LIU, C.T., A new glass-forming ability criterion for bulk metallic glasses, Acta Materialia. 50, 2002, p.3501-3512.

11.RAMAKRISHNA RAO, B., Bulk Metallic Glasses: Materials of Future, 214 DRDO Science Spectrum. 2009, p.212-218.

12.INOUE, A., FAN C, SAIDA, J., ZHANG, T., High-strength Zr-based bulk amorphous alloys containing nanocrystalline and nanoquasicrystalline particles. Science and Technology of Advanced Materials. 2000;1(2):73-86.

13.QIANG, J.B., ZHANG, W., XIE, G.Q., INOUE, A., The effect of Ti, Nb, and Ta additions to ZrAlCu metallic glass on the crystallization and formation of the icosahedral phase, J. Mater. Res., Vol. 22, No. 4, 2007, p.1093-1097

14.INOUE, A., TAKEUCHI, A., Recent Progress in Bulk Glassy Alloys, Materials Transactions. 43, 2002, p. 1892-1906. 
15.JANG, J.S.C., CHANG, L.J., CHEN, G.J., HUANG, J.C., Crystallization behavior of the $\mathrm{Zr}_{63} \mathrm{Al}_{7.5} \mathrm{Cu}_{17.5} \mathrm{Ni}_{10} \mathrm{~B}_{2}$ amorphous alloy during isothermal annealing. In: Intermetallics. 2005 ; Vol. 13, No. 8. p. 907-911.

16.CASTILHO, A. V., SANTOS, D. S. Effect of Sn Addition in the Microstructure Refinement and Corrosion Resistance of Cu-Zr-Al-Ag Alloy. Materials Research, 22(2), e20171139. Epub April 04, 2019

17.Schroers, J., Kumar, G., Hodges, T., Chan, S., Kyriakides, T., (2009). Bulk metallic glasses for biomedical applications. JOM. 61. 21-29. 10.1007/s11837-009-0128-1.

18JAFARY-ZADEH, M., KUMAR, G., BRANICIO, P., SEIFI, M., LEWANDOWSKI, J., CUI, F.. A Critical Review on Metallic Glasses as Structural Materials for Cardiovascular Stent Applications. Journal of Functional Biomaterials. 9. 19. 10.3390/jfb9010019, 2018.

19.SURYANARAYANA, C., INOUE, A., Iron-based bulk metallic glasses, International Materials Reviews. 58, 2013, p.131-166.

20. MONDAL, K., MURTY, B.S., On the parameters to assess the glass forming ability of liquids, Journal of Non-Crystalline Solids, 351, 2005, p.1366-1371.

Manuscript received: 11.11 .2019 